\title{
Adult Obesity and Health-Related Quality of Life, Patient Activation, Work Productivity, and Weight Loss Behaviors in the United States
}

This article was published in the following Dove Press journal: Diabetes, Metabolic Syndrome and Obesity: Targets and Therapy

\author{
Heather Rozjabek' \\ John Fastenau' \\ Anne LaPrade (D) ${ }^{2}$ \\ Nikoletta Sternbach ${ }^{2}$ \\ 'Janssen Global Services, Raritan, NJ, \\ USA; ${ }^{2}$ Kantar, New York, NY, USA
}

Correspondence: John Fastenau Janssen Global Services, LLC, 700 US-202, Raritan, NJ 08869, USA

Tel + I 908429 I872

Email JFastena@its.jnj.com

\begin{abstract}
Introduction: While it is generally believed that people living with more severe obesity experience greater negative impacts on health-related quality of life (HRQoL), their experience may be impacted by other factors such as age, gender, and type 2 diabetes mellitus (T2DM).
\end{abstract}

Methods: The 36-Item Short Form Health Survey physical component score and mental component score, Work Productivity and Activity Impairment, and Patient Activation Measure $^{\circledR}$ data from the 2018 National Health and Wellness Survey were analyzed in adults by body mass index (BMI) categories (normal weight: $\geq 18.5-<25 \mathrm{~kg} / \mathrm{m}^{2}$, overweight: $\geq 25-$ $<30 \mathrm{~kg} / \mathrm{m}^{2}$, class 1 obesity: $\geq 30-<35 \mathrm{~kg} / \mathrm{m}^{2}$, class 2 obesity: $\geq 35-<40 \mathrm{~kg} / \mathrm{m}^{2}$, class 3 obesity: $\geq 40 \mathrm{~kg} / \mathrm{m}^{2}$, combined class $2 / 3$ obesity: $\geq 35 \mathrm{~kg} / \mathrm{m}^{2}$ ). Findings were further stratified across age groups (young: $18-35 y$, middle-aged: $36-64 y$, older: $\geq 65 y$ ), by gender, and by T2DM status Results: Overall, as BMI increased people had greater negative effects on HRQoL, felt less involved with and in control of their healthcare, and had greater work productivity and activity impairments. The largest declines were generally observed between class 2 and 3 obesity categories. Young adults with obesity were more likely to feel less engaged with their health care than middle-aged/older adults with obesity. The effects of obesity on HRQoL and patient activation were generally consistent by gender. People with T2DM and obesity tended to have greater declines in physical functioning and more work and activity impairments than people with obesity without T2DM. The proportion of people trying to lose weight increased with increasing BMI category, and people with T2DM were less likely to exercise and more likely to diet than those without T2DM.

Conclusion: Increasing levels of obesity tended to have a greater negative impact on HRQoL, patient activation, work productivity, and weight loss behaviors, but some differences in effects by age, gender, and T2DM status were observed.

Keywords: obesity, health-related quality of life, HRQoL, activation, productivity, behaviors

\section{Introduction}

Obesity is now recognized as a chronic disease that increases morbidity and mortality risks. Each individual's experience living with obesity is unique, and individuals may perceive different negative impacts associated with this disease such as impaired physical, emotional, and social functioning as well as poor self-image and selfesteem. ${ }^{1}$ Physiological, psychological and behavioral factors contributing to obesity are also consequences of this disease highlighting the complexity of the illness. Therefore, there is a need to better understand how obesity impacts the way people 
feel and function, including changes in hunger and appetite control, physical function, and social, mental, and emotional well-being. ${ }^{1}$ It is generally believed that people with severe obesity experience greater negative impacts on health-related quality of life (HRQoL), but the experience of obesity may also be impacted by other demographic characteristics and comorbid conditions. This analysis aimed to generate further insights into how obesity affects daily life by examining HRQoL, patient engagement with health care, work productivity, and weight loss behaviors in US adults by age, gender, and type 2 diabetes mellitus (T2DM) status. These insights could be used to increase awareness among providers about obesity-related HRQoL concerns that may affect their patients and the need to consider the individual's personal context and specific health determinants when communicating with them and offering treatment options.

\section{Patients and Methods}

The National Health and Wellness Survey (NHWS) is a crosssectional, self-reported survey; in the 2018 data fielded from February-July 2018, adults $\geq 18$ y were surveyed in the United States using a stratified random sampling based on gender, age, and race/ethnicity to ensure representativeness to the adult population (based on US Census Bureau data). Comparisons between NHWS and other established sources (US Census, National Health Interview Survey, National Health and Nutrition Examination Survey, etc.) have been published elsewhere. The protocol and questionnaire for the NHWS were reviewed by the Pearl Institutional Review Board (Indianapolis, IN) and exempted from review for the current retrospective analysis due to the use of existing HIPAA compliant data. All NHWS respondents provided informed consent prior to their participation. Kantar Health conducted the NHWS and received funding for access to the data.

NHWS examines patients' attitudes, behaviors, characteristics, and demographics, and condition-specific information, including health care resource utilization and patient-reported outcomes. $^{2}$ The NHWS includes multiple measures of patientreported outcomes as described below. The 36-Item Short Form Health Survey (SF-36v2) measures 8 physical and psychosocial domains and overall mental and physical quality of life through a mental component score (MCS) and a physical component score (PCS). ${ }^{3}$ The Work Productivity and Activity Impairment (WPAI) questionnaire measures overall work productivity and activity impairment by quantifying general health perceptions and global measures of interference with regular activity. ${ }^{4}$ The Patient Activation Measure $^{\circledR}\left(\mathrm{PAM}^{\circledR}\right)$ measures a patient's engagement with their own health care. ${ }^{5,6}$ PAM levels $1-4$ correspond to people who are "disengaged and overwhelmed," "becoming aware but still struggling," "taking action and gaining control," and "maintaining behaviors and pushing further," respectively. ${ }^{5}$ The NHWS also contains questions on self-reported weight loss behaviors and reports a Charlson comorbidity index (CCI) which was used to evaluate the overall comorbidity burden.

SF-36v2 scores, WPAI scores, PAM levels, and survey results were analyzed and categorized by World Health Organization-defined body mass index (BMI) categories (normal weight: BMI $\geq 18.5-<25 \mathrm{~kg} / \mathrm{m}^{2}$, overweight: BMI $\geq 25-<30 \mathrm{~kg} / \mathrm{m}^{2}$, class 1 obesity: BMI $\geq 30-<35 \mathrm{~kg} / \mathrm{m}^{2}$, class 2 obesity: BMI $\geq 35-<40 \mathrm{~kg} / \mathrm{m}^{2}$, class 3 obesity: BMI $\left.\geq 40 \mathrm{~kg} / \mathrm{m}^{2}\right){ }^{7}$ Results were also calculated for the combined class $2 / 3$ obesity group.

The relationship between NHWS results and BMI categories was also examined in bivariate analyses ( $t$-test, chi square tests) with differences tested at the 0.05 alpha level. No adjustments were made for multiplicity. Effects were analyzed across age groups (young: 18-35y, middle-aged: $36-64 y$, older: $\geq 65 y$ ), by gender, and by T2DM status.

\section{Results}

\section{Population Characteristics Characteristics of the Overall Population}

In the overall population of 69,742 adult respondents with BMI $\geq 18.5 \mathrm{~kg} / \mathrm{m}^{2}$, a lower proportion of older adults were classified as class $2 / 3$ obesity than those $<65$ y (Table 1 ); approximately $45 \%$ of adults with class 3 obesity were $\leq 44 y$. African Americans were overrepresented in all obesity classes, and Hispanics were overrepresented in obesity class 2 compared with other weight classes (all $P<0.05$ ). People with any class of obesity were less likely to have a college-level education than those who were normal weight or overweight $(P<0.05)$. Individuals with class $2 /$ 3 obesity were more likely to have an annual household income $<\$ 50,000$ than those with lower BMIs $(P<0.05)$. Adults with class $2 / 3$ obesity had higher CCI scores and were most likely to report multiple comorbidities including T2DM, mental health issues, arthritis, respiratory issues, and cardiovascular conditions (all $P<0.05$ ).

\section{Characteristics and Comorbidities by Age, Gender, and T2DM Status}

The proportion of adults with obesity was greatest in the middle-aged group (36-64y). Across all age groups, females made up the majority of people with class 3 
Table I Demographics and Baseline Characteristics by Body Weight Category

\begin{tabular}{|c|c|c|c|c|c|c|}
\hline & $\begin{array}{l}\text { Normal Weight } \\
(\mathrm{BMI} \geq 18.5- \\
\left.<25 \mathrm{~kg} / \mathrm{m}^{2}\right)\end{array}$ & $\begin{array}{l}\text { Overweight } \\
\text { (BMI } \geq 25- \\
<30 \mathrm{~kg} / \mathrm{m}^{2} \text { ) }\end{array}$ & $\begin{array}{l}\text { Class I Obesity } \\
(\mathrm{BMI} \geq 30- \\
\left.<35 \mathrm{~kg} / \mathrm{m}^{2}\right)\end{array}$ & $\begin{array}{l}\text { Class } 2 \text { Obesity } \\
(\mathrm{BMI} \geq 35- \\
\left.<40 \mathrm{~kg} / \mathrm{m}^{2}\right)\end{array}$ & $\begin{array}{l}\text { Class } 3 \\
\text { Obesity (BMI } \\
\geq 40 \mathrm{~kg} / \mathrm{m}^{2} \text { ) }\end{array}$ & $\begin{array}{l}\text { Combined Class } 2 \text { and } 3 \\
\text { Obesity }\left(\text { BMI } \geq 35 \mathrm{~kg} / \mathrm{m}^{2}\right)\end{array}$ \\
\hline $\begin{array}{l}\text { Total population, } \mathrm{n} \\
\text { Total weighted } \\
\text { population (represented } \\
\text { in thousands) } \\
\text { Mean age, years }\end{array}$ & $\begin{array}{l}24,841 \\
78,479\end{array}$ & $\begin{array}{l}22,442 \\
74,006 \\
50.4^{\mathrm{a}, \mathrm{d}, \mathrm{e}, \mathrm{f}}\end{array}$ & $\begin{array}{l}12,101 \\
41,293 \\
51.0^{\mathrm{a}, \mathrm{b}, \mathrm{d}, \mathrm{e}, \mathrm{f}}\end{array}$ & $\begin{array}{l}5768 \\
20,258 \\
\\
48.9^{\mathrm{a}, \mathrm{e}}\end{array}$ & $\begin{array}{l}4590 \\
15,850 \\
46.9^{\mathrm{a}}\end{array}$ & $\begin{array}{l}10,358 \\
36,108 \\
48.0^{\mathrm{a}}\end{array}$ \\
\hline $\begin{array}{l}\text { Age category, } \% \\
\text { 18-34 years } \\
35-44 \text { years } \\
45-54 \text { years } \\
55-64 \text { years } \\
\geq 65 \text { years }\end{array}$ & $\begin{array}{l}39.2^{\mathrm{b}, \mathrm{c}, \mathrm{d}, \mathrm{e}, \mathrm{f}} \\
15.6 \\
14.1 \\
13.5^{\mathrm{e}} \\
17.6^{\mathrm{e}}\end{array}$ & $\begin{array}{l}22.9^{\mathrm{c}} \\
15.8 \\
17.7^{\mathrm{a}} \\
18.7^{\mathrm{a}} \\
25.0^{\mathrm{a}, \mathrm{d}, \mathrm{e}, \mathrm{f}}\end{array}$ & $\begin{array}{l}20.5 \\
15.5 \\
19.5^{\mathrm{a}, \mathrm{b}} \\
20.4^{\mathrm{a}, \mathrm{b}} \\
24.2^{\mathrm{a}, \mathrm{d}, \mathrm{e}, \mathrm{f}}\end{array}$ & $\begin{array}{l}23.1^{\mathrm{c}} \\
17.5^{\mathrm{a}, \mathrm{b}, \mathrm{c}} \\
19.6^{\mathrm{a}, \mathrm{b}} \\
20.5^{\mathrm{a}, \mathrm{b}} \\
19.3^{\mathrm{a}, \mathrm{e}}\end{array}$ & $\begin{array}{l}24.7^{\mathrm{b}, \mathrm{c}} \\
20.2^{\mathrm{a}, \mathrm{b}, \mathrm{c}, \mathrm{d}} \\
21.8^{\mathrm{a}, \mathrm{b}, \mathrm{c}, \mathrm{d}} \\
19.1^{\mathrm{a}} \\
14.2\end{array}$ & $\begin{array}{l}23.8^{\mathrm{c}} \\
18.7^{\mathrm{a}, \mathrm{b}, \mathrm{c}} \\
20.6^{\mathrm{a}, \mathrm{b}} \\
19.9^{\mathrm{a}, \mathrm{b}} \\
17.0\end{array}$ \\
\hline $\begin{array}{l}\text { Gender, \% } \\
\text { Female } \\
\text { Male }\end{array}$ & $\begin{array}{l}56.9^{\mathrm{b}, c, \mathrm{~d}} \\
43.1^{\mathrm{e}}\end{array}$ & $\begin{array}{l}43.9 \\
56.1^{\mathrm{a}, \mathrm{c}, \mathrm{d}, \mathrm{e}, \mathrm{f}}\end{array}$ & $\begin{array}{l}48.4^{\mathrm{b}} \\
51.6^{\mathrm{a}, \mathrm{d}, \mathrm{e}, \mathrm{f}}\end{array}$ & $\begin{array}{l}53.7^{\mathrm{b}, \mathrm{c}} \\
46.3^{\mathrm{a}, \mathrm{e}}\end{array}$ & $\begin{array}{l}60.2^{\mathrm{a}, \mathrm{b}, \mathrm{c}, \mathrm{d}} \\
39.8\end{array}$ & $\begin{array}{l}56.6^{\mathrm{b}, \mathrm{c}} \\
43.4\end{array}$ \\
\hline $\begin{array}{l}\text { Race/Ethnicity, \% } \\
\text { White } \\
\text { Hispanic } \\
\text { African American } \\
\text { American Indian } \\
\text { Asian } \\
\text { Mixed } \\
\text { Other }\end{array}$ & $\begin{array}{l}62.1 \\
15.7 \\
10.8 \\
0.4 \\
8.1^{\text {b.c,d,e,f }} \\
2.0 \\
1.0\end{array}$ & $\begin{array}{l}65.0^{\mathrm{a}, \mathrm{d}, \mathrm{f}} \\
15.7 \\
11.2 \\
0.6^{\mathrm{a}} \\
4.6^{\mathrm{c}, \mathrm{d}, \mathrm{e}, \mathrm{f}} \\
1.8 \\
1.1\end{array}$ & $\begin{array}{l}65.0^{\mathrm{a}, \mathrm{d}} \\
15.8 \\
13.1^{\mathrm{a}, \mathrm{b}} \\
0.7^{\mathrm{a}} \\
2.4^{\mathrm{d}, \mathrm{e}, \mathrm{f}} \\
2.0 \\
1.1\end{array}$ & $\begin{array}{l}63.1 \\
17.2^{\mathrm{a}, \mathrm{b}, \mathrm{c}, \mathrm{e}} \\
14.3^{\mathrm{a}, \mathrm{b}} \\
0.6 \\
1.4^{\mathrm{e}} \\
2.4^{\mathrm{b}} \\
0.9\end{array}$ & $\begin{array}{l}64.2^{\mathrm{a}} \\
15.1 \\
15.4^{\mathrm{a}, \mathrm{b}, \mathrm{c}} \\
0.6 \\
0.8 \\
3.0^{\mathrm{a}, \mathrm{b}, \mathrm{c}} \\
1.0\end{array}$ & $\begin{array}{l}63.6^{\mathrm{a}} \\
16.3 \\
14.8^{\mathrm{a}, \mathrm{b}, \mathrm{c}} \\
0.6^{\mathrm{a}} \\
1.1 \\
2.7^{\mathrm{a}, \mathrm{b}, \mathrm{c}} \\
0.9\end{array}$ \\
\hline $\begin{array}{l}\text { Marital status, \% } \\
\text { Married } \\
\text { Single, never married } \\
\text { Divorced } \\
\text { Separated } \\
\text { Widowed } \\
\text { Living with partner } \\
\text { Decline to answer }\end{array}$ & $\begin{array}{l}41.4 \\
37.0^{\mathrm{b}, \mathrm{c}, \mathrm{d}, \mathrm{e}, \mathrm{f}} \\
8.7 \\
1.0 \\
4.5^{\mathrm{a}} \\
7.2^{\mathrm{b}} \\
0.3^{\mathrm{c}, \mathrm{d}, \mathrm{f}}\end{array}$ & $\begin{array}{l}50.3^{\mathrm{a}, c, d, e, f} \\
26.7^{\mathrm{c}} \\
10.0^{\mathrm{a}} \\
1.2 \\
5.2^{\mathrm{a}} \\
6.3 \\
0.2\end{array}$ & $\begin{array}{l}48.9^{\mathrm{a}, \mathrm{d}, \mathrm{e}, \mathrm{f}} \\
25.5 \\
11.5^{\mathrm{a}, \mathrm{b}} \\
1.4^{\mathrm{a}} \\
5.9^{\mathrm{a}, \mathrm{b}, \mathrm{d}, \mathrm{e}, \mathrm{f}} \\
6.7 \\
0.2\end{array}$ & $\begin{array}{l}44.6^{\mathrm{a}, \mathrm{e}} \\
29.8^{\mathrm{b}, \mathrm{c}} \\
12.4^{\mathrm{a}, \mathrm{b}} \\
1.7^{\mathrm{a}, \mathrm{b}} \\
4.9 \\
6.5 \\
0.1\end{array}$ & $\begin{array}{l}40.7 \\
34.0^{\mathrm{b}, c, \mathrm{~d}} \\
11 . .^{\mathrm{a}, \mathrm{b}} \\
1.8^{\mathrm{a}, \mathrm{b}} \\
5.0 \\
7.1 \\
0.2\end{array}$ & $\begin{array}{l}42.9^{\mathrm{a}} \\
31.7^{\mathrm{b}, \mathrm{c}} \\
11.9^{\mathrm{a}, \mathrm{b}} \\
1 . .^{\mathrm{a}, \mathrm{b}} \\
4.9 \\
6.8 \\
0.2\end{array}$ \\
\hline $\begin{array}{l}\text { Household income, \% } \\
\qquad \$ 25,000 \\
\$ 25,000-<\$ 50,000 \\
\$ 50,000-<\$ 75,000 \\
\$ 75,000-<\$ 100,000 \\
\$ 100,000-<\$ 125,000 \\
\$ 125,000-<\$ 150,000 \\
\$ 150,000-<\$ 200,000 \\
\geq \$ 200,000 \\
\text { Decline to answer }\end{array}$ & $\begin{array}{l}17.9^{\mathrm{b}} \\
23.7^{-} \\
18.8^{\mathrm{c}} \\
13.4^{\mathrm{c}, \mathrm{d}, \mathrm{e}, \mathrm{f}} \\
7.8^{\mathrm{c}, \mathrm{d}, \mathrm{e}, \mathrm{f}} \\
4.7^{\mathrm{d}, \mathrm{e}, \mathrm{f}} \\
3.7^{c, \mathrm{~d}, \mathrm{e}, \mathrm{f}} \\
3.5^{\mathrm{c}, \mathrm{d}, \mathrm{e}, \mathrm{f}} \\
6.6^{\mathrm{b}, \mathrm{c}, \mathrm{d}, \mathrm{e}, \mathrm{f}}\end{array}$ & $\begin{array}{l}15.7 \\
25.5^{\mathrm{a}} \\
19.6^{\mathrm{a}, \mathrm{e}} \\
13.7^{\mathrm{c}, \mathrm{d}, \mathrm{e}, \mathrm{f}} \\
7.9^{\mathrm{c}, \mathrm{d}, \mathrm{e}, \mathrm{f}} \\
5.0^{\mathrm{c}, \mathrm{d}, \mathrm{e}, \mathrm{f}} \\
4.0^{\mathrm{c}, \mathrm{d}, \mathrm{e}, \mathrm{f}} \\
3.1^{\mathrm{c}, \mathrm{d}, \mathrm{e}, \mathrm{f}} \\
5.3^{\mathrm{d}, \mathrm{e}, \mathrm{f}}\end{array}$ & $\begin{array}{l}18.9^{\mathrm{a}, \mathrm{b}} \\
27.6^{\mathrm{a}, \mathrm{b}} \\
19.6^{\mathrm{e}} \\
12.4^{\mathrm{e}, \mathrm{f}} \\
6.8^{\mathrm{d}, \mathrm{e}, \mathrm{f}} \\
4.4^{\mathrm{d}, \mathrm{e}, \mathrm{f}} \\
3.2^{\mathrm{d}, \mathrm{e}, \mathrm{f}} \\
2.2^{\mathrm{d}, \mathrm{e}, \mathrm{f}} \\
4.9^{\mathrm{e}, \mathrm{f}}\end{array}$ & $\begin{array}{l}23.7^{\mathrm{a}, \mathrm{b}, \mathrm{c}} \\
28.1^{\mathrm{a}, \mathrm{b}} \\
19.3 \\
11.5^{\mathrm{e}} \\
5.8^{\mathrm{e}} \\
3.3 \\
2.6^{\mathrm{e}} \\
1.6^{\mathrm{e}} \\
4.3\end{array}$ & $\begin{array}{l}29.4^{\mathrm{a}, \mathrm{b}, \mathrm{c}, \mathrm{d}} \\
30.2^{\mathrm{a}, \mathrm{b}, \mathrm{c}, \mathrm{d}} \\
17.9 \\
9.3 \\
4.6 \\
2.5 \\
1.6 \\
0.9 \\
3.6\end{array}$ & $\begin{array}{l}26.2^{\mathrm{a}, \mathrm{b}, \mathrm{c}} \\
29.0^{\mathrm{a}, \mathrm{b}, \mathrm{c}} \\
18.7 \\
10.6 \\
5.3 \\
2.9 \\
2.1 \\
1.2 \\
4.0\end{array}$ \\
\hline $\begin{array}{l}\text { Level of education, \% } \\
\text { High school or less } \\
\text { Some college or } \\
\text { associate's degree } \\
\text { College graduate } \\
\text { Decline to answer }\end{array}$ & $\begin{array}{l}23.3 \\
40.1 \\
36.4^{\mathrm{b}, \mathrm{c}, \mathrm{d}, \mathrm{e}, \mathrm{f}} \\
0.2^{\mathrm{c}, \mathrm{d}, \mathrm{e}, \mathrm{f}}\end{array}$ & $\begin{array}{l}22.6 \\
42.9^{\mathrm{a}} \\
34.4^{\mathrm{c}, \mathrm{d}, \mathrm{e}, \mathrm{f}} \\
0.1^{\mathrm{f}}\end{array}$ & $\begin{array}{l}24.3^{\mathrm{b}} \\
46.6^{\mathrm{a}, \mathrm{b}} \\
29.0^{\mathrm{d}, \mathrm{e}, \mathrm{f}} \\
0.1\end{array}$ & $\begin{array}{l}26.0^{\mathrm{a}, \mathrm{b}, \mathrm{c}} \\
49.7^{\mathrm{a}, \mathrm{b}, \mathrm{c}} \\
24.3^{\mathrm{e}} \\
0.05\end{array}$ & $\begin{array}{l}28.7^{\mathrm{a}, \mathrm{b}, \mathrm{c}, \mathrm{d}} \\
49.9^{\mathrm{a}, \mathrm{b}, \mathrm{c}} \\
21.3 \\
0.02\end{array}$ & $\begin{array}{l}27.2^{\mathrm{a}, \mathrm{b}, \mathrm{c}} \\
49.8^{\mathrm{a}, \mathrm{b}, \mathrm{c}} \\
23.0 \\
0.03\end{array}$ \\
\hline Mean $\mathrm{CCl}$ score & 0.32 & $0.41^{\mathrm{a}}$ & $0.56^{\mathrm{a}, \mathrm{b}}$ & $0.64^{\mathrm{a}, \mathrm{b}, \mathrm{c}}$ & $0.75^{\mathrm{a}, \mathrm{b}, \mathrm{c}, \mathrm{d}}$ & $0.68^{a, b, c}$ \\
\hline
\end{tabular}

(Continued) 
Table I (Continued).

\begin{tabular}{|c|c|c|c|c|c|c|}
\hline & $\begin{array}{l}\text { Normal Weight } \\
(B M I \geq 18.5- \\
\left.<25 \mathrm{~kg} / \mathrm{m}^{2}\right)\end{array}$ & $\begin{array}{l}\text { Overweight } \\
(\text { BMI } \geq 25- \\
<30 \mathrm{~kg} / \mathrm{m}^{2} \text { ) }\end{array}$ & $\begin{array}{l}\text { Class I Obesity } \\
(\mathrm{BMI} \geq 30- \\
\left.<35 \mathrm{~kg} / \mathrm{m}^{2}\right)\end{array}$ & $\begin{array}{l}\text { Class } 2 \text { Obesity } \\
(\mathrm{BMI} \geq 35- \\
\left.<40 \mathrm{~kg} / \mathrm{m}^{2}\right)\end{array}$ & $\begin{array}{l}\text { Class } 3 \\
\text { Obesity (BMI } \\
\geq 40 \mathrm{~kg} / \mathrm{m}^{2} \text { ) }\end{array}$ & $\begin{array}{l}\text { Combined Class } 2 \text { and } 3 \\
\text { Obesity }\left(B M I \geq 35 \mathrm{~kg} / \mathrm{m}^{2}\right)\end{array}$ \\
\hline $\mathrm{CCl}$ score, \% & & & & & & \\
\hline 0 & $82.8^{\mathrm{b}, \mathrm{c}, \mathrm{d}, \mathrm{e}, \mathrm{f}}$ & $75.2^{\mathrm{c}, \mathrm{d}, \mathrm{e}, \mathrm{f}}$ & $67.7^{\mathrm{d}, \mathrm{e}, \mathrm{f}}$ & $64.1^{\mathrm{e}}$ & 58.4 & 61.6 \\
\hline 1 & 10.0 & $15.8^{\mathrm{a}}$ & $19.8^{\mathrm{a}, \mathrm{b}}$ & $20.9^{\mathrm{a}, \mathrm{b}}$ & $24.5^{\mathrm{a}, \mathrm{b}, \mathrm{c}, \mathrm{d}}$ & $22.5^{\mathrm{a}, \mathrm{b}, \mathrm{c}}$ \\
\hline 2 & 4.2 & $5.5^{\mathrm{a}}$ & $7.1^{\mathrm{a}, \mathrm{b}}$ & $8.7^{\mathrm{a}, \mathrm{b}, \mathrm{c}}$ & $9.2^{\mathrm{a}, \mathrm{b}, \mathrm{c}}$ & $8.9^{\mathrm{a}, \mathrm{b}, \mathrm{c}}$ \\
\hline 3 & 1.3 & $1.8^{\mathrm{a}}$ & $2.9^{\mathrm{a}, \mathrm{b}}$ & $3.4^{\mathrm{a}, \mathrm{b}}$ & $4.3^{\mathrm{a}, \mathrm{b}, \mathrm{c}, \mathrm{d}}$ & $3.8^{\mathrm{a}, \mathrm{b}, \mathrm{c}}$ \\
\hline$\geq 4$ & 1.6 & 1.6 & $2.5^{\mathrm{a}, \mathrm{b}}$ & $2.9^{\mathrm{a}, \mathrm{b}}$ & $3.7^{\mathrm{a}, \mathrm{b}, \mathrm{c}}$ & $3.2^{\mathrm{a}, \mathrm{b}, \mathrm{c}}$ \\
\hline T2DM, \% & 3.3 & $9.1^{\mathrm{a}}$ & $15.2^{\mathrm{a}, \mathrm{b}}$ & $19.7^{\mathrm{a}, \mathrm{b}, \mathrm{c}}$ & $25.3^{\mathrm{a}, \mathrm{b}, \mathrm{c}, \mathrm{d}}$ & $22.1^{\mathrm{a}, \mathrm{b}, \mathrm{c}}$ \\
\hline
\end{tabular}

Notes: ${ }^{a} P<0.05$ compared with normal weight. ${ }^{b} P<0.05$ compared with overweight. ${ }^{c} P<0.05$ compared with class $I$ obesity. ${ }^{d} P<0.05$ compared with class 2 obesity. ${ }^{\text {e }} P<0.05$ compared with class 3 obesity. ${ }^{f} P<0.05$ compared with combined class $2 / 3$ obesity.

Abbreviations: BMI, body mass index; $\mathrm{CCl}$, Charlson Comorbidity Index; T2DM, type 2 diabetes mellitus.

obesity, and this differential was most pronounced in older adults. The comorbidity profile varied between the age groups, with young adults across BMI classes reporting the highest rates of anxiety (46-59\%), bipolar disorder (7-12\%), migraine (26-36\%), and social anxiety disorder (SAD; 17-26\%). Middle-aged and older adults with obesity had higher rates of arthritis and type 2 diabetes than those in lower BMI categories (all $P<0.05$ ).

The rate of T2DM increased with increasing obesity, from $15 \%$ among those with class 1 obesity to $25 \%$ with class 3 obesity. Among adults with T2DM, only 16\% of the class 3 obese population was $<45 \mathrm{y}$; in contrast, among those without T2DM, $54 \%$ of adults with class 3 obesity were $<45$ y ( Supplemental Table 1).

\section{Obesity-Related Impacts on HRQoL} Impacts on HRQoL in the Overall Population

HRQoL decreased with increasing BMI, as measured by SF-36v2 scores (Figure 1A). The greatest decreases in MCS and PCS were observed between class 2 and 3 obesity. People in higher BMI classes were more likely to report a PAM level of 2 and less likely to report a PAM level of 4 (Figure 1B).

Among individuals employed full time, loss of work productivity increased with increasing BMI, up to $24.3 \%$ in people with class 3 obesity (Figure 1C). Activity impairment also increased with BMI class, up to $39.9 \%$ among those with class 3 obesity.

\section{Impacts on HRQoL by Age, Gender, and T2DM} Status

Compared with people with BMI $<25 \mathrm{~kg} / \mathrm{m}^{2}$, young and middle-aged adults with class $2 / 3$ obesity had a lower mean MCS, as measured by the SF-36v2 (both $P<0.05$ ).
A greater proportion of young adults reported a PAM level of 1 or 2 than middle-aged and older adults for most obesity classes.

Across all age groups, people with class 3 obesity had greater activity impairment than people with class 2 obesity (all $P<0.05$ ). Although few older adults reported being employed, those $\geq 65 \mathrm{y}$ with class 3 obesity reported higher rates of work productivity loss compared with normal weight adults $(18.7 \%$ vs $10.8 \%, P<0.05)$.

Overall, the effects of obesity on HRQoL and patient activation were generally consistent between males and females. Across obesity classes, mean MCS and PCS scores tended to be slightly lower for females than for males. Females tended to have slightly higher PAM scores than males. In general, obese females had higher rates of absenteeism, presenteeism, productivity loss, and activity impairment compared with obese males.

Across BMI categories, people with T2DM tended to have lower mean SF-36v2 PCS but similar MCS compared with people without T2DM. The effects of obesity on PAM scores were similar in those with and without T2DM. Among people with and without T2DM, greater proportions of adults with class $2 / 3$ obesity had a PAM level of 2, and lower proportions had a PAM level of 4; PAM levels generally decreased as BMI class increased.

Across BMI categories, people with obesity and T2DM tended to report similar rates of absenteeism but higher rates of presenteeism and productivity loss compared with people with obesity without T2DM. Across all BMI classes, people with T2DM tended to report higher rates of activity impairment compared with those without T2DM (eg, $43.2 \%$ vs $33.0 \%$ for people with class $2 / 3$ obesity). 
A

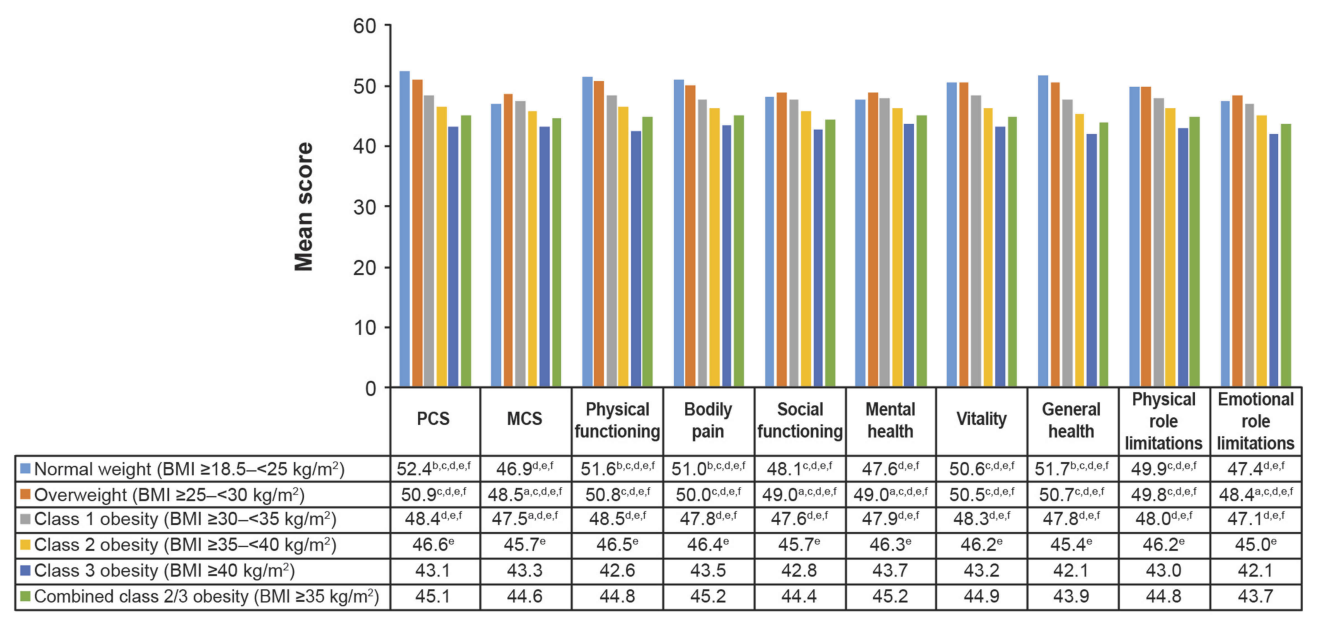

B

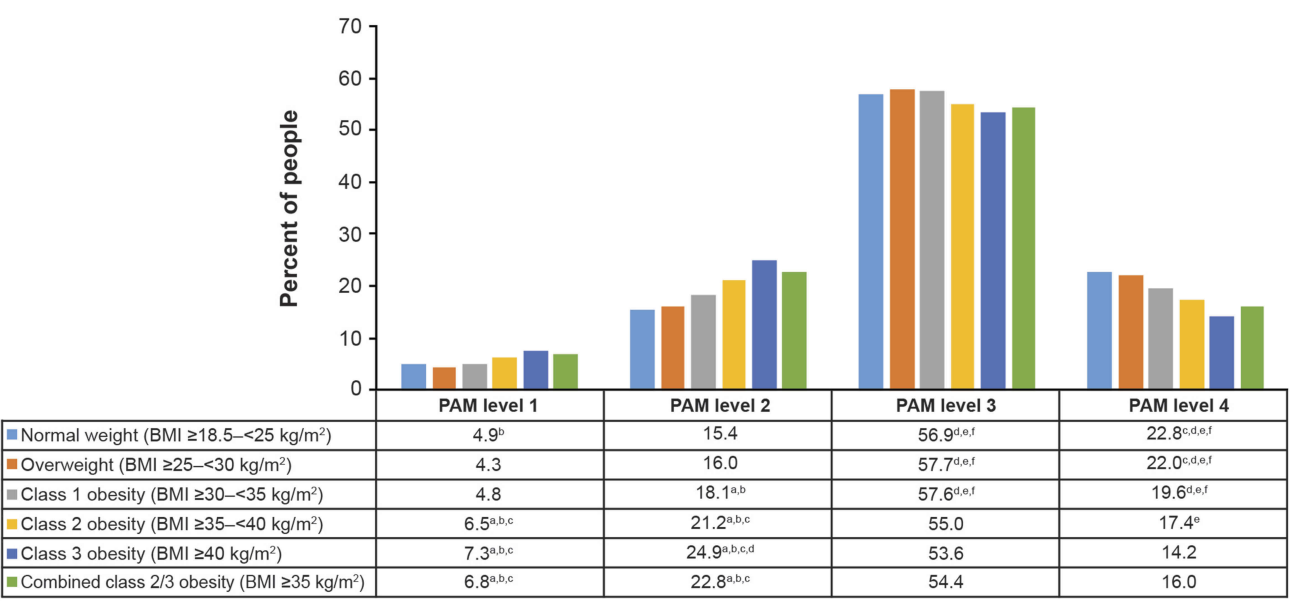

C

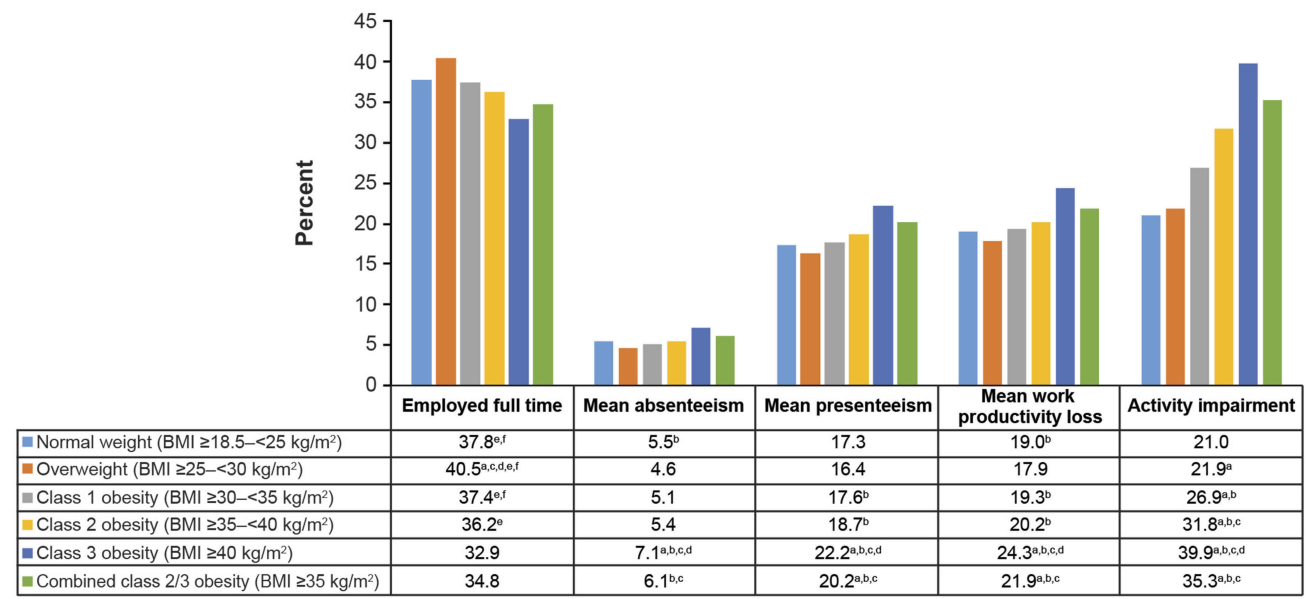

Figure I NHWS Results by BMI Category (A) Mean SF-36v2, (B) PAM, and (C) WPAI Scores.

Notes: ${ }^{\text {a }} \mathrm{P}<0.05$ compared with normal weight. ${ }^{\mathrm{b}} \mathrm{P}<0.05$ compared with overweight. ${ }^{\mathrm{C}} \mathrm{P}<0.05$ compared with class $\mathrm{I}$ obesity. ${ }^{\mathrm{d}} \mathrm{P}<0.05$ compared with class 2 obesity. ${ }^{\mathrm{e}} \mathrm{P}<0.05$ compared with class 3 obesity. ${ }^{f} \mathrm{P}<0.05$ compared with combined class $2 / 3$ obesity.

Abbreviations: BMI, body mass index; MCS, mental component score; NHWS, National Health and Wellness Survey; PAM ${ }^{\circledR}$, Patient Activation Measure ${ }^{\circledR}$; PCS, physical component score; SF-36v2, 36-Item Short Form Health Survey; WPAI, Work Productivity and Activity Impairment. 


\section{Weight Loss Behaviors}

The proportion of adults who reported that they were trying to lose weight increased with increasing BMI category, from $63 \%$ of people with class 1 obesity to $69 \%$ of people with class 3 obesity (Supplemental Table 2). The proportion of people with class 3 obesity trying to lose weight was similar across age groups (65-70\%), and among those with any class of obesity, a similar proportion of males and females reported taking steps to lose weight. A larger proportion of females than males in the overweight BMI class reported taking steps to lose weight ( $58 \%$ vs $43 \%$ ). Most people who were overweight and obese wanted to lose weight to improve their general health.

Among those trying to lose weight, the proportion of people using a diet increased from $77 \%$ for class 1 obesity to $80 \%$ for class 3 obesity $(P<0.05)$. Conversely, the proportion of adults using exercise to lose weight decreased from $70 \%$ with class 1 obesity to $59 \%$ with class 3 obesity $(P<0.05)$. Among all respondents, the number of days exercised in the past month decreased with increasing BMI category, from 7 days for people with class 1 obesity to 4 days with class 3 obesity $(P<0.05)$. Across BMI categories, people with T2DM tended to be less likely to exercise and more likely to diet than those without T2DM.

Among those trying to lose weight, the use of weight management programs, over-the-counter medication, and prescription drugs was $<7 \%,<6 \%$, and $<4 \%$, respectively, for any class of obesity. Only $63 \%$ of adults with class 3 obesity who were trying to lose weight had discussed the steps they were taking to lose weight with their doctor, and rates decreased among those in lower BMI categories (all $P<0.05$ ); people with T2DM tended to talk with their doctor about losing weight more than people without T2DM. Adults who were trying to lose weight had higher average PAM scores than those not trying to lose weight (63.7 vs $62.4 ; P<0.05$ ).

Among those trying to lose weight, about one-third remained the same weight, and about half lost weight within the past 6 months. The amount of weight lost increased with increasing obesity category from 17 to 22 pounds in people with class 1 and class 3 obesity $(P<0.05)$. Compared to people without T2DM, those with T2DM tended to have higher rates of weight loss.

\section{Discussion}

This analysis suggested that living with obesity was associated with meaningful reductions in HRQoL, patient activation, and work productivity across age, gender, and
T2DM status subgroups. As BMI increased, people had greater negative effects on HRQoL, felt less involved with and in control of their health care, and had greater work productivity and activity impairments. The largest declines in HRQoL were generally observed between class 2 and 3 obesity.

Young adults with obesity had higher rates of certain comorbidities and may be more likely to feel less engaged with their health care than middle-aged and older adults with obesity. The effects of obesity appeared similar in males and females, though females with obesity reported greater impairments in work activities than males. People with T2DM and obesity tended to have greater declines in physical functioning and more work and activity impairments than people with obesity but without T2DM; this may also be related to the older age of those with T2DM.

Across BMI categories, people commonly reported using diet and/or exercise to lose weight and infrequently used other weight loss methods such as medication and bariatric surgery, despite the potential for significant weight loss with these methods. People with T2DM were less likely to exercise than those without T2DM but were more likely to have discussed weight loss with their doctor.

This analysis was limited by the cross-sectional nature of the NHWS and the use of bivariate statistics. Future research to understand disease-related impacts on people living with obesity could expand on these insights by assessing hypothesis-driven analyses utilizing more rigorous longitudinal study designs and multivariate analytic methods. Another limitation of our analysis is the dependence of BMI categories defined by the World Health Organization. BMI is a measure of height and weight and does not necessarily reflect the "health" or the presence of disease in an individual. BMI does not account for body shape and composition differences related to gender or race/ethnicity; however, BMI is often used to determine "healthy weight ranges" for populations consistent with the application of use in our analysis.

Our results highlight that obesity is a heterogeneous disease. Increasing levels of obesity tended to have a greater negative impact on HRQoL, patient activation, work productivity, and weight loss behaviors, but there were some differences in effects by age, gender, and T2DM status. These findings advocate that chronic weight management programs be individualized based on the current health status and overall weight loss goals of the person living with obesity. 


\section{Abbreviations}

BMI, body mass index; CCI, Charlson Comorbidity Index; HRQoL, health-related quality of life; MCS, mental component score; NHWS, National Health and Wellness Survey; PAM $^{\circledR}$, Patient Activation Measure ${ }^{\circledR}$; PCS, physical component score; SAD, social anxiety disorder; SF-36v2, 36-Item Short Form Health Survey; T2DM, type 2 diabetes mellitus; WPAI, Work Productivity and Activity Impairment.

\section{Acknowledgments}

Medical writing support was provided by Dana Tabor, $\mathrm{PhD}$, of MedErgy, and funded by Janssen Research \& Development, LLC.

\section{Funding}

This study was supported by Janssen Research \& Development, LLC. The study sponsor was involved in the study design and decision to submit the paper for publication.

\section{Disclosure}

H.R. and J.F. are full-time employees of Janssen Global Services, LLC. A.L. and N.S. are full-time employees of
Kantar. The authors report no other conflicts of interest in this work.

\section{References}

1. Fastenau J, Kolotkin RL, Fujioka K, Alba M, Canovatchel W, Traina S. A call to action to inform patient-centred approaches to obesity management: development of a disease-illness model. Clin Obes. 2019;9(3):e12309.

2. Kantar Health. National Health and Wellness Survey: patient-reported healthcare insights. Available from: https://www.kantarhealth.com/ docs/datasheets/kh-national-health-and-wellness-survey.pdf. Accessed August 9, 2019

3. Maruish ME, ed. User's Manual for the SF-36v2 Health Survey. 3rd ed. Lincoln (RI): QualityMetric, Inc; 2011.

4. Reilly MC, Zbrozek AS, Dukes EM. The validity and reproducibility of a work productivity and activity impairment instrument. Pharmacoeconomics. 1993;4(5):353-365. doi:10.2165/00019053199304050-00006

5. Insignia Health ${ }^{\circledR}$. Patient Activation Measure ${ }^{\circledR}\left(\mathrm{PAM}^{\circledR}\right)$. 2003-2017 University of Oregon. All rights reserved. Available from: https:// www.insigniahealth.com/products/pam-survey. Accessed August 9, 2019.

6. Hibbard JH, Stockard J, Mahoney ER, Tusler M. Development of the Patient Activation Measure (PAM): conceptualizing and measuring activation in patients and consumers. Health Serv Res. 2004;39(4 Pt 1):1005-1026. doi:10.1111/j.1475-6773.2004.00269.x

7. World Health Organization. Global strategy on diet, physical activity and health. Available from: https://www.who.int/dietphysicalactivity/ childhood_what/en. Accessed August 9, 2019.

\section{Publish your work in this journal}

Diabetes, Metabolic Syndrome and Obesity: Targets and Therapy is an international, peer-reviewed open-access journal committed to the rapid publication of the latest laboratory and clinical findings in the fields of diabetes, metabolic syndrome and obesity research. Original research, review, case reports, hypothesis formation, expert opinion and commentaries are all considered for publication. The manuscript management system is completely online and includes a very quick and fair peer-review system, which is all easy to use. Visit http://www.dovepress.com/testimonials.php to read real quotes from published authors. 